\title{
Accumulation and Perchlorate Exposure Potential of Lettuce Produced in the Lower Colorado River Region
}

\author{
C. A. Sanchez,${ }^{\dagger}$ R. I. Krieger,${ }^{\dagger}$ N. Khandaker, ${ }^{\dagger}$ R. C. Moore, ${ }^{\S}$ \\ K. C. HOLTS ${ }^{\S}$ AND L. L. NEIDEL ${ }^{\S}$ \\ Department of Soil, Water, and Environmental Sciences, Yuma Agricultural Center, \\ The University of Arizona, Yuma, Arizona, 85364, Personal Chemical Exposure Program, \\ Department of Entomology, University of California-Riverside, Riverside, California 92521, \\ Environmental Decisions and Program Development, Sandia National Laboratories, \\ Albuquerque, New Mexico 87185
}

\begin{abstract}
The Colorado River is contaminated with perchlorate concentrations of $1.5-8 \mu \mathrm{g} / \mathrm{L}$, an anion linked to thyroid dysfunction. Over $90 \%$ of the lettuce (Lactuca sativa L.) consumed during the winter months in the United States is produced in the Lower Colorado River region. Studies were conducted in this region to survey the potential for lettuce perchlorate accumulation and estimate potential human exposure to perchlorate from lettuce. Total uptake of perchlorate in the above-ground plant of iceberg lettuce was approximately $5 \mathrm{~g} / \mathrm{ha}$. Exposure estimates ranged from 0.45 to $1.8 \mu \mathrm{g} /$ day depending on lettuce types and trimming. For all lettuce types, hypothetical exposures were less than $4 \%$ of the reference dose recommended by the National Academy of Sciences. Results show the relative iodide uptake inhibition potential because of lettuce nitrate was 2 orders of magnitude greater than that associated with the corresponding trace levels of perchlorate. These data support the conclusion that potential perchlorate exposures from lettuce irrigated with Colorado River water are negligible relative to acute or long-term harmful amounts.
\end{abstract}

KEYWORDS: Perchlorate exposure; nitrate; Lactuca sativa L.; iceberg lettuce; romaine lettuce; leaf lettuce; butterhead lettuce

\section{INTRODUCTION}

Perchlorate has been discovered in surface and groundwater supplies throughout the United States. There is concern that these perchlorate-contaminated waters may represent a health risk both as sources of drinking water to humans and irrigation water to food crops. Perchlorate has the potential to cause thyroid dysfunction by inhibiting iodide uptake by the sodium iodide symporter (NIS) (1). A number of other inorganic anions, including nitrate, can act as goitrogens by blocking iodide uptake of the NIS in a competitive manner $(2,3)$. Although nitrate is less potent of an iodide uptake inhibitor of the NIS than perchlorate, it is naturally present in leafy vegetables $(4,5)$.

Perchlorate in the Colorado River is introduced into Lake Mead through contamination by a perchlorate salt-manufacturing plant associated with aerospace and munitions industries on the Las Vegas wash. It has been reported that the Colorado River below Lake Mead has perchlorate concentrations ranging from 5 to $9 \mathrm{ppb}(6)$. The production of fresh market vegetables in the lower Colorado regions of Arizona and California is a 2

* To whom correspondence should be addressed. Telephone: (520) 782 3836. Fax: (520) 782-1940. E-mail: sanchez@ag.arizona.edu.

The University of Arizona.

$\div$ University of California-Riverside.

$\S$ Sandia National Laboratories. billion dollar industry. Essentially, $100 \%$ of this industry relies on Colorado River water for irrigation, and there is concern that consumption of perchlorate through food produced in the region may represent a significant source of exposure.

Several plant species have been shown to absorb and accumulate perchlorate from soil and irrigation water. Perchlorate has been detected in salt cedar (Tamarix ramosissima) (7) and other plant species (8) growing in the Las Vegas wash. Accumulation of perchlorate in tobacco fields previously fertilized with perchlorate containing Chilean nitrate is also wellestablished (9). Accumulation by Salix sp (10) and Myriophyllum aquaticum (11) has been studied for phytoremediation.

There is also evidence that perchlorate accumulates in certain food crops. This was initially inferred from studies with pertechnetate. Pertechnetate is chemically similar to perchlorate and is often considered an analogue for the study of perchlorate (12). Numerous studies have shown that perchlorate or pertechnetate is absorbed and accumulates in leaves but not to the same extent that they accumulate in the fruits of food plants $(13-16)$.

Perchlorate accumulation in crops where leaves are consumed is a present concern. Hutchinson et al. (17) found perchlorate accumulated in lettuce during early growth stages under glasshouse conditions. At the request of the Environmental Working Group, The Institute of Environmental and Human 


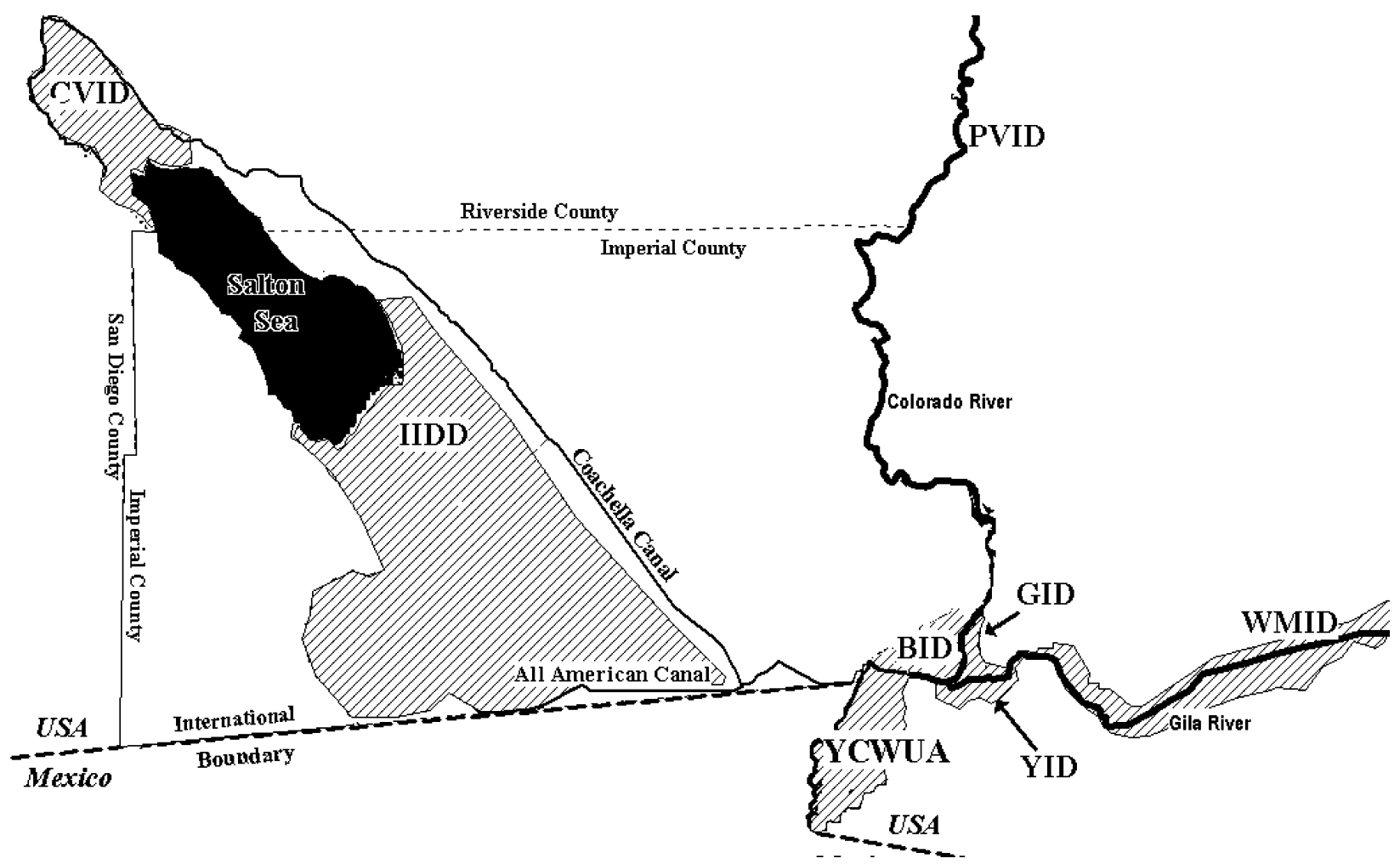

Figure 1. Lower Colorado River region including Coachella and Imperial Valley of California, Lower Colorado River Valley of California and Arizona, and Gila River Valleys of Arizona.

Health of Texas Tech University analyzed 22 leafy vegetable samples purchased in Northern California in the winter of 20022003 (18). Presumably, these samples were from the lower Colorado River region because they were purchased in the winter months when most of the leafy produce is shipped from this region. A total of 4 of the 22 samples contained detectable levels of perchlorate, with 1 as high as $121 \mu \mathrm{g} / \mathrm{kg}$ on a fresh weight (fw) basis. More recently, the FDA in a preliminary "bread basket" survey found perchlorate in lettuce irrigated with Colorado River water to range from below quantifiable levels to $129 \mu \mathrm{g} / \mathrm{kg}$ of fw (19).

Fertilizer is sometimes considered a potential source of perchlorate to plants. Chilean nitrate has long been known to be a natural source of perchlorate (20). A recent comprehensive evaluation has shown that, with the exception of fertilizers derived from Chilean nitrate, fertilizers are not a significant source of perchlorate to the environment (21). A limited amount of Chilean nitrate has been used in vegetable, fruit, and tobacco production systems. Currently, it is sometimes used in organic production systems, because it is the only form of mineral $\mathrm{N}$ allowed. However, it is estimated that less the $0.1 \%$ of the $\mathrm{N}$ fertilizer used in the United States is derived from Chilean nitrate. A recent survey by the USGS has found perchlorate in other agricultural amendments (22) including blood meal, fishmeal, and kelp. Natural processes are likely responsible for the perchlorate in the southern high plains of Texas (23). It is likely that irrigation water is the major source of perchlorate in lettuce produced in the lower Colorado River region. However, because perchlorate can sometimes occur in some fertilizers, amendments, and naturally, other sources cannot completely be ruled out. More work is needed to identify all potential natural and anthropogenic sources of perchlorate in the environment.

Over 60000 ha of lettuce are produced in the lower Colorado River region of Arizona and California each year. Lettuce is seeded from early September through late January and harvested from early November through early April each year. The confluence of the Colorado and Gila Rivers occurs north of the international border in Yuma County, AZ. Lettuce is produced in the former alluvial flood plains of the Colorado and Gila River Valleys as well as the Coachella and Imperial Valleys of California. The Imperial (IIDD) and Coachella Valleys (CVID) of California are irrigated with Colorado River water diverted into the "All American Canal" at the Imperial Diversion Dam (Figure 1). Production along the Gila River including the North Gila Valley ((Gila Irrigation District (GID)), South Gila Valley ((Yuma Irrigation District (YID)), and the Wellton-Mohawk Irrigation and Drainage District (WMIDD) are also irrigated with Colorado River water transported in canals from the Imperial Diversion Dam. The Yuma County Water Users Association (YCWUA) and the Bard Irrigation and Drainage Districts (BID) deliver Colorado River water to the Arizona side and the California sides, respectively, at the southern U.S. boundary of the lower Colorado River Valley.

The objectives of this project were to conduct a preliminary survey of the potential for lettuce produced in the lower Colorado River Region to accumulate perchlorate, estimate potential human exposure to perchlorate from lettuce types produced in the region, and estimate the possible biologic significance of perchlorate relative to nitrate in lettuce.

\section{MATERIALS AND METHODS}

Uptake and Accumulation of Perchlorate in Iceberg Lettuce. These initial evaluations focused on iceberg lettuce because it is the lettuce type produced on the largest land area. All fields sampled were irrigated with Colorado River water. In the 2002-2003 winter-spring season, fields in the Lower Colorado River Valley of Arizona (Yuma), the Gila Valley (North and South), and the Wellton-Mohawk Irrigation and Drainage District were sampled in February. These would represent fields seeded in October and November. In the 2003-2004 fall-winter season, fields in these same areas were sampled from November to January. These would represent fields seeded in September and early October. After the location was recorded, we took seven whole plants 
at random from each 40acre field sampled and transported them to our laboratory. Three plants were processed as whole above-ground plants. Four plants were partitioned into wrapper and frame leaves and trimmed naked edible heads. The weights of each portion were recorded. These samples were then diced and mixed thoroughly, and a subsample was placed in the freezer.

During 2003-2004, samples were also collected from one location to study uptake and distribution of perchlorate in iceberg lettuce during the growing season. This evaluation was located on a site in Yuma seeded October 7, 2003. Four replicate samples were collected at key growth stages throughout the growing season. The number of plant samples composited into each replicate varied by plant age and size and ranged from 400 plants at the two-leaf growth stage to two plants at maturity. The 1-2 leaf, 6-7 leaf, folding, heading, and maturity growth stages occurred 8, 24, 43, 54, and 100 days after planting, respectively. For each replicate on each sampling date, one set of plants was separated into whole above-ground plants and roots. Another set was collected for more detailed partitioning. As the plant developed, this second set was partitioned from the outer leaves inward. For example, as the plant grew, we separated the outer four leaves (1-4 $\mathrm{L})$, the next four inner leaves $(5-8 \mathrm{~L})$, the next four inner leaves (9$12 \mathrm{~L}$ ), and the core or head. The weights of each portion were recorded. These samples were then diced and mixed thoroughly, and a subsample was placed in the freezer.

Survey and Exposure Estimate of Perchlorate for Iceberg, Romaine, Leaf, and Butter Lettuce Types. An expanded survey was conducted for exposure estimates including all major lettuce types produced in the Lower Colorado River region. All fields selected for sampling were irrigated with water from the Colorado River. Iceberg and romaine lettuce samples were collected from different production regions. Areas sampled included the Coachella Valley and Imperial Valley of California and the Lower Colorado River Valley of California (Bard) and Arizona (Yuma). Iceberg and romaine lettuce samples were collected in the middle of December and in early February. Product harvested in December would have been seeded in September, and product harvested in February would have been seeded in October and November. Iceberg lettuce samples were sampled as naked, wrapped, and bulk trim commercial packs. Naked lettuce represents minimal trimming and is boxed unwrapped. Wrapped lettuce involves the removal of a few extra wrapper leaves, prior to wrapping in plastic, compared to naked packed lettuce. Bulk lettuce is used for packaged salads and involves the removal of even more wrapper leaves and usually the stem core. Romaine was sampled as naked, bulk, and heart trim. Bulk romaine involves partial removal of the stem core and the partial severing of the upper and outer leaf blade margins. Romaine hearts involve the removal of most leaves, with the heart being the only marketable product. Green leaf, red leaf, and butter head were harvested only in the naked form in early March. These products would have been seeded in December. All lettuce samples were collected and trimmed in the field to meet standard types of marketable product. In all cases, field samples were taken at commercial harvest with the assistance of the harvest manager and/or harvesters. In each case, four plants were composited into each sample and four composite samples were collected in each field sampled. Samples were diced and mixed thoroughly, and a subsample was placed in the freezer.

Sample Processing and Extraction for Perchlorate. The frozen samples were freeze-dried as space became available on a Labconco freeze drier. Weights before and after freeze-drying were recorded. Lettuce typically took $48 \mathrm{~h}$ for complete freeze-drying. The samples were ground and stored in vials for extraction. We used an extraction procedure described previously (24) with minor modifications. Briefly, $600 \mathrm{mg}$ of freeze-dried product was weighed into centrifuge tubes, and $15 \mathrm{~mL}$ of DI water was added. The tubes were boiled for $30 \mathrm{~min}$, and the contents were placed in a refrigerator overnight with occasional gentle shaking. The tubes were then centrifuged for $30 \mathrm{~min}$, and the supernatants were filtered through Kim wipes and $0.2 \mu \mathrm{m}$ Gel-man ion membrane syringe filters. A total of $2 \mathrm{~mL}$ of the above extract (extract one) was reacted with $1000 \mathrm{mg}$ of DD-alumina. Vials were gently agitated 2-3 times over a 24-h period. A total of $18 \mathrm{~mL}$ of DI water was then added to this mixture. After stirring and settling, this solution was filtered through another $0.2 \mu \mathrm{m}$ Gel-man ion membrane syringe filter and the resulting solution was labeled "extract 2 ". This sample was stored in the freezer until analysis by ion chromatography (IC). Before loading on the IC, extracts were allowed to reach room temperature and were filtered through preconditioned (methanol and water) Dionex "On Guard" RP syringe filters. Furthermore, the first $0.75 \mathrm{~mL}$ of sample (extract 2) pushed through the filter is discarded, and the remaining aliquots are used for IC analysis.

Perchlorate Analysis. All perchlorate analyses were performed on a Dionex model 2500 ion chromatograph consisting of an IP 25 isocratic pump, an EG50 eluent generator, a continuous regenerating trap column, a CD 25 conductivity detector, the $2 \mathrm{~mm}$ AG16/AS16 guard and separation column pair, and an AMMS III suppressor. The columns, suppressor, and detector are housed in a LC 30 chromatography oven. We used a $50 \mathrm{mM} \mathrm{KOH}$ eluent and $50 \mathrm{mM}$ sulfuric acid suppression. A $1000 \mu \mathrm{L}$ injection loop was used, and elution times ranged from 9.5 to $11.0 \mathrm{~min}$. Calibration was performed with standards ranging from 0.5 to $100 \mu \mathrm{g} / \mathrm{L}$. Ideally, one should calibrate in matrix, but this is difficult to do for environmental and biological specimens because matrices are not constant. Therefore, we guarded against matrix errors by spiked additions. A minimum of $10 \%$ of the lettuce samples were extracted with a $100 \mu \mathrm{g} / \mathrm{L}$ perchlorate standard to yield $10 \mu \mathrm{g} / \mathrm{L}$ perchlorate after dilution. The method detection limit (MDL) was determined using the procedure outlined in EPA method 314.0 (25) using seven replicates of a standard in reagent water. The calculated MDL was $0.2 \mu \mathrm{g} / \mathrm{L}$ using a $0.5 \mu \mathrm{g} / \mathrm{L}$ standard. We set the MRL for lettuce extracts at $1.5 \mu \mathrm{g} / \mathrm{L}$. As a standard practice, we would run $10 \%$ duplicate extractions in addition to the $10 \%$ spiked additions. Duplicate aliquots of a given extraction were always analyzed. Additional aliquots or replicates were analyzed if we judged that the variability on the first two aliquots or replicates was excessive. In addition, duplicate extracts for approximately $10 \%$ of all samples were sent out to a commercial laboratory for confirmatory analysis by IC/MS/MS. The IC/MS/MS procedure employs a Dionex ICS 2500, an eluant generator programmed to provide a mobile phase composition of $35 \mathrm{mM}$ potassium hydroxide, a Dionex ASRS Ultra II $2 \mathrm{~mm}$ ion suppression unit, and a 2 mm AG16/AS16 column pair. The MS/MS detector used is a Waters Quattro Ultima detector. This instrument is configured with an electrospray probe interface. The instrument is operated in the multiple-reaction monitoring mode (MRM). Hexapole prefilters reduce noise levels and focus the ion beam into the quadropole systems. The first stage filters for the molecular ion of the two major chlorine isotopes for perchlorate and one isotope for the ${ }^{18} \mathrm{O}$ internal standard. One oxygen atom is removed from the perchlorate ions in the second stage (collision cell) of the detector. The third stage filters for the oxygen loss ion of perchlorate.

Nitrate Analysis of Plant Tissue. Nitrate in freeze-dried plant tissue was determined potentiometrically (26). Approximately $400 \mathrm{mg}$ of tissue and $0.04 \mathrm{~L}$ of $\mathrm{Al}_{2}\left(\mathrm{SO}_{4}\right)_{3}$ buffer solution were placed in $250 \mathrm{~mL}$ Erlenmeyer flasks, put on a shaker for $30 \mathrm{~min}$, and filtered. The filtrates were analyzed for nitrate using a calibrated nitrate-selective electrode and potentiometer.

Perchlorate Concentration in Irrigation Water. Aliquots of composite Colorado River water samples, collected by the U.S. Bureau of Reclamation (USBOR) from March 2003 to April 2004, were analyzed for perchlorate using a modification of EPA method 314.0 (25). These measurements were compared to samples collected upstream at Willow Beach by the Nevada Division of Environmental Protection from December 2002 to April 2004.

Exposure Estimates. As noted previously, our reporting level for perchlorate was set at $1.5 \mu \mathrm{g} / \mathrm{L}$ for lettuce extracts. Depending on the moisture content of lettuce and based on extraction and dilution, ratios employed corresponded to approximately $20 \mu \mathrm{g} / \mathrm{kg}$ of fw for iceberg lettuce and $25-30 \mu \mathrm{g} / \mathrm{kg}$ of fw perchlorate for all other lettuce types. For human-exposure calculations, we assumed that lettuce samples having perchlorate concentrations less than the MRL contained perchlorate at $10 \mu \mathrm{g} / \mathrm{kg}$ for iceberg lettuce and $15 \mu \mathrm{g} / \mathrm{kg}$ for all other lettuce types. We used an estimate of $5 \mu \mathrm{g} / \mathrm{kg}$ for all levels below detection for all lettuce types. Although these assumptions might overestimate actual perchlorate exposures, we deemed it prudent to be conservative with the exposure estimates. For calculations of exposure and dosage, 


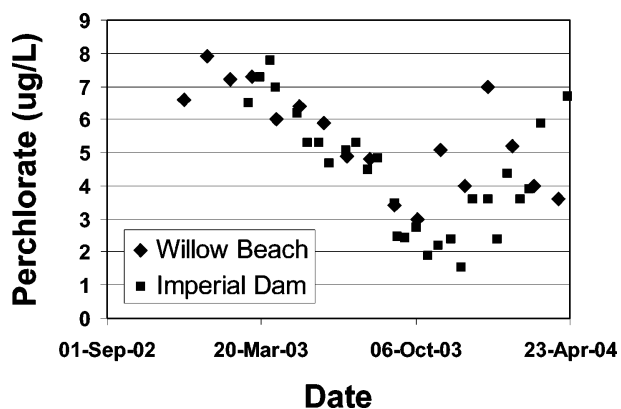

Figure 2. Perchlorate concentration of the Colorado River during the study period.

we assumed a daily consumption of $55 \mathrm{~g}$ (27) of lettuce and an average adult body weight of $70 \mathrm{~kg}$.

\section{RESULTS AND DISCUSSION}

Perchlorate concentrations in the Colorado River over the lettuce production period of these surveys ranged from 1.5 to 8 $\mu \mathrm{g} / \mathrm{L}$ (Figure 2). Perchlorate concentrations of water samples collected at Willow Beach, 11 miles downstream of Lake Mead, generally correspond closely to those that we measured at Imperial Diversion Dam, 290 miles downstream of Lake Mead. There were a couple of exceptions. For example, at Imperial Dam, we did not observe the spike in concentration measured at Willow Beach in January and February of 2004. Conversely, at Imperial Dam, we measured a spike in concentration in April 2004 that was observed at Willow Beach. Diversions, storage, and tributaries between Willow Beach and Imperial Dam would likely cause some differences in concentrations of perchlorate measured at these sampling points. Overall, these values for perchlorate concentration generally agree with values determined from periodic grab samples collected by the Arizona Department of Environmental Quality (28).

Studies have shown that perchlorate in soils is largely transported into and through soils with irrigation water with no physical or chemical retention by the soils $(29,30)$. It is possible for perchlorate to temporarily accumulate in the crop-rooting zone when evapotranspiration (ET) exceeds leaching. Nevertheless, because lettuce is salt-sensitive, growers typically apply irrigation water to achieve leaching fractions to preclude detrimental salt accumulation. Therefore, over a growing period, the perchlorate concentration of the irrigation water is a reasonable estimate of potential plant availability.

The average concentration of perchlorate in irrigation water over the survey period was close was to $5 \mathrm{mg} / \mathrm{L}$. Lettuce typi- cally receives $50 \mathrm{~cm}$ of irrigation water, and we would therefore estimate total perchlorate applied to a lettuce crop in irrigation water to be approximately $25 \mathrm{~g} / \mathrm{ha}$. However, this would include the water applied for leaching salts as well. It should be noted that this water leaching below the root zone is a potential source of contamination to drainage systems and groundwater, and additional work to address this potential impact is needed. A better estimate of potential perchlorate accumulation might be obtained from ET estimates for lettuce, which is approximately $25 \mathrm{~cm}(31,32)$, giving a potential perchlorate accumulation of $12-13 \mathrm{~g} / \mathrm{ha}$.

Overall, a comparison of perchlorate concentrations measured by IC with duplicate extracts sent out for IC/MS/MS confirmatory analysis show good agreement (slope of 1.1 and $R^{2}$ of 0.93 ). Actual estimates of perchlorate concentration and accumulation by iceberg lettuce over a growing season are shown in Table 1. Interestingly, perchlorate accumulation was highest in the outer leaves and decreased as the lettuce was partitioned inward toward the edible core. It is likely that perchlorate moves into plants in the transpiration stream and accumulates as water transpires through the leaves (33). For iceberg lettuce, transpiration largely occurs in the outer leaves. The results of a survey with iceberg lettuce corroborate these findings, indicating most of the perchlorate accumulated in the outer frame and wrapper leaves and not the edible head (Table 2). Perchlorate concentrations in the total above-ground plant ranged from below quantifiable levels to $142 \mu \mathrm{g} / \mathrm{kg}$ of fw, while concentrations in the frame and wrapper leaves ranged from below quantifiable levels to $195 \mu \mathrm{g} / \mathrm{kg}$ of fw. Amounts in the edible head ranged from below detection to $26 \mu \mathrm{g} / \mathrm{kg}$ of fw. The frame leaves are typically left in the field after harvesting, and the grocer and/or consumer trim the wrapper leaves. The edible core represents the portion typically consumed.

These data show total above-ground perchlorate accumulation for iceberg lettuce was approximately $5 \mathrm{~g} / \mathrm{ha}$ (Table 1). This value is consistent with amounts calculated from the survey data in Table 2. The reasons for total perchlorate accumulation being less than the estimated potential accumulation are unknown. It may be due to microbially mediated reduction of perchlorate in soil water at anaerobic microsites in the soil (34) or in the root rhizophere (35); it may be associated with some plant selectivity rather than purely passive uptake; or it may be a biochemical reduction within the plant $(10,36)$. Additional work is needed to understand factors and mechanisms affecting plant uptake, transport, and transformations of perchlorate.

We were interested in estimating potential exposure of perchlorate through various lettuce types produced in the

Table 1. Concentration and Accumulation of Perchlorate in the Various Fractions of Iceberg Lettuce and in Whole Above-Ground Plants during the Growing Season When Irrigated with Colorado River Water

\begin{tabular}{|c|c|c|c|c|c|}
\hline \multirow[b]{2}{*}{ growth stage } & \multicolumn{5}{|c|}{ plant part } \\
\hline & 1st-4th outer leaves & 5th-8th outer leaves & 9th-12th outer leaves & head & whole plant \\
\hline \multicolumn{6}{|c|}{ Perchlorate Concentration $(\mu \mathrm{g} / \mathrm{kg}$ of $\mathrm{fw})$} \\
\hline 1-2 leaf & & & & & $170(28)$ \\
\hline $6-7$ leaf & $110(14)^{a}$ & $28(13)$ & & & $102(5)$ \\
\hline folding & $169(17)$ & $100(13)$ & $70(19)$ & & $102(46)$ \\
\hline heading & $208(40)$ & $89(21)$ & $73(20)$ & $<M R L$ & $89(18)$ \\
\hline maturity & $108(18)$ & $79(5)$ & $46(14)$ & $<\mathrm{MRL}$ & $53(41)$ \\
\hline \multicolumn{6}{|c|}{ Perchlorate Accumulation (g/ha) } \\
\hline 1-2 leaf & & & & & $0.0005(0.00006)$ \\
\hline $6-7$ leaf & $0.0160(0.0025)$ & $0.00087(0.00040)$ & & & $0.0178(0.0021)$ \\
\hline folding & $0.125(0.016)$ & $0.156(0.033)$ & $0.100(0.036)$ & & $0.42(0.20)$ \\
\hline heading & $0.39(0.03)$ & $0.30(0.10)$ & $0.30(0.07)$ & $<M R L$ & $1.17(0.60)$ \\
\hline maturity & $0.66(0.13)$ & $0.74(0.02)$ & $0.24(0.06)$ & $<M R L$ & $5.1(0.41)$ \\
\hline
\end{tabular}

a Values in parentheses show standard deviations. 
Table 2. Perchlorate Content in Whole Above-Ground Iceberg Lettuce Plants and Contents of Plants Separated into Combined Frame and Wrapper Leaves and the Trimmed Naked Edible Head during the Winter-Spring 2002-2003 and Fall-Winter 2003-2004

\begin{tabular}{|c|c|c|c|}
\hline \multirow[b]{2}{*}{ sample } & \multicolumn{3}{|c|}{ perchlorate concentration $(\mu \mathrm{g} / \mathrm{kg})$ fresh weight } \\
\hline & $\begin{array}{c}\text { frame and } \\
\text { wrapper leaves }\end{array}$ & head & $\begin{array}{l}\text { whole above- } \\
\text { ground plant }\end{array}$ \\
\hline \multicolumn{4}{|c|}{ winter-spring } \\
\hline \multicolumn{4}{|c|}{$2002-2003$} \\
\hline 1 & 94 & $<\mathrm{MRL}^{a}$ & 37 \\
\hline 2 & 90 & $<\mathrm{MRL}$ & 32 \\
\hline 3 & 44 & not detectable & $<M R L$ \\
\hline 4 & $<M R L$ & not detectable & $<M R L$ \\
\hline 5 & 62 & $<\mathrm{MRL}$ & 27 \\
\hline 6 & $<M R L$ & not detectable & $<\mathrm{MRL}$ \\
\hline 7 & 42 & $<\mathrm{MRL}$ & $<M R L$ \\
\hline 8 & 58 & not detectable & $<M R L$ \\
\hline 9 & 45 & not detectable & 25 \\
\hline 10 & 78 & $<M R L$ & 33 \\
\hline 11 & 52 & $<M R L$ & 28 \\
\hline 12 & 48 & $<\mathrm{MRL}$ & 29 \\
\hline 13 & 63 & $<M R L$ & 27 \\
\hline 14 & 63 & $<\mathrm{MRL}$ & $<\mathrm{MRL}$ \\
\hline 15 & 39 & not detectable & 27 \\
\hline 16 & 77 & $<M R L$ & 28 \\
\hline 17 & 52 & $<M R L$ & 21 \\
\hline 18 & 55 & 23 & 30 \\
\hline 19 & 43 & $<M R L$ & 22 \\
\hline 20 & 64 & $<M R L$ & $<M R L$ \\
\hline 21 & 55 & $<M R L$ & $<M R L$ \\
\hline 22 & 56 & $<M R L$ & $<M R L$ \\
\hline 23 & 56 & 25 & 23 \\
\hline 24 & 65 & $<M R L$ & 22 \\
\hline \multicolumn{4}{|l|}{ fall-winter } \\
\hline \multicolumn{4}{|l|}{ 2003-2004 } \\
\hline 25 & 109 & $<M R L$ & 65 \\
\hline 26 & 56 & $<M R L$ & 49 \\
\hline 27 & 195 & $<M R L$ & 142 \\
\hline 28 & 59 & 26 & 43 \\
\hline 29 & 162 & $<M R L$ & 44 \\
\hline 30 & 44 & $<M R L$ & 23 \\
\hline 31 & 74 & $<\mathrm{MRL}$ & 34 \\
\hline 32 & 40 & $<M R L$ & $<M R L$ \\
\hline 33 & 30 & $<\mathrm{MRL}$ & $<M R L$ \\
\hline 34 & 121 & $<M R L$ & 81 \\
\hline 35 & 100 & $<\mathrm{MRL}$ & 70 \\
\hline 36 & 55 & $<M R L$ & 49 \\
\hline 37 & 55 & 23 & 38 \\
\hline 38 & 112 & 23 & 27 \\
\hline 39 & $<M R L$ & $<M R L$ & $<M R L$ \\
\hline 40 & 58 & $<M R L$ & 22 \\
\hline 41 & 43 & $<M R L$ & 44 \\
\hline 42 & 77 & $<M R L$ & 34 \\
\hline 43 & 55 & $<M R L$ & 37 \\
\hline 44 & 89 & $<\mathrm{MRL}$ & 46 \\
\hline
\end{tabular}

${ }^{a}<\mathrm{MRL}$ represents a detectable peak among duplicates and/or replicates but below a level that can be quantitated.

Colorado River region. Furthermore, because iceberg and romaine lettuce are marketed in different commercial trims, we sought to also evaluate exposure as influenced by trimming. Trimming can reduce plant mass primarily by removing outer leaves by as much as 20 and 35\% for wrapped and bulk, respectively, from a naked pack for iceberg lettuce (Table 3). We observed little difference in mass between naked and bulk romaine, but trimming to hearts reduced mass by as much as $49 \%$. Leaf and butter head lettuce types are almost exclusively marketed as a naked pack.

Perchlorate concentrations ranged from below detection to $104 \mu \mathrm{g} / \mathrm{kg}$ of $\mathrm{fw}$, and mean perchlorate exposure estimates ranged from 0.45 to $1.8 \mu \mathrm{g} / \mathrm{day}$, depending on the lettuce type and trimming (Table 4). For iceberg and romaine lettuce,
Table 3. Mean Weights of Lettuce Types and Trims

\begin{tabular}{cc}
\hline $\begin{array}{c}\text { lettuce type } \\
\text { and trim }\end{array}$ & marketable plant mass $(\mathrm{g})$ \\
\hline iceberg & \\
naked & $902.0(65.6)^{a}$ \\
wrapped & $718.2(88.3)$ \\
bulk & $583.5(111.4)$ \\
romaine & \\
naked & $604.8(86.3)$ \\
bulk & $612.0(82.6)$ \\
hearts & $310.4(101.6)$ \\
green leaf & $365.3(45.0)$ \\
red leaf & $438.9(84.4)$ \\
butter & $255.6(54.9)$
\end{tabular}

${ }^{a}$ Values in parentheses show standard deviations.

perchlorate exposure decreased by more than $40 \%$ with trimming. Products with the least trimming, including naked romaine, green leaf, red leaf, and butter head lettuce, showed the greater potential exposure $(1.5 \mu \mathrm{g} /$ day or more). These lettuce types have a more open leaf structure compared to iceberg lettuce, likely resulting in more transpiration in more of the leaves, thereby resulting in more accumulation of perchlorate in the edible portions. The FDA used LC/MS/MS in a recent market basket survey, which provides for much lower detection compared to the IC method used here (37). The FDA data set is smaller than that presented here, and they did not distinguish trimming. However, estimates of exposure calculated for their data were $0.49,1.07,0.80$, and $0.49 \mu \mathrm{g}$ /day for iceberg, romaine, green leaf, and red leaf, respectively. These values are similar but slightly lower than estimates that we report (Table 4) but provide some confirmation that our estimates may be a little conservative as we intended.

Currently, there is uncertainty surrounding how environmental perchlorate exposure should be regulated. Perhaps the best initial reference points for comparative exposure assessment in food products are perchlorate levels allowed in water. Reference levels in water that are potentially relevant to the Lower Colorado River region are shown in Table 5. The Environmental Protection Agency (EPA) had proposed a drinking water equivalent level (DWEL) of $1 \mu \mathrm{g} / \mathrm{L}$. This proposed EPA standard was derived from a no observed adverse effect level (NOAEL) determined from studies with laboratory animals and includes an uncertainty factor of 300 and an $80 \%$ relative source contribution assumption (38). Within the California Environmental Protection Agency, The Office of Environmental Health Hazard Assessment (OEHHA) (39) has established a public health goal of $6 \mu \mathrm{g} / \mathrm{L}$ in drinking water based on a bench mark dose (BMD) calculated from iodide uptake inhibition in human test subjects (40) and includes an uncertainty factor of 10 and a relative source contribution assumption of $60 \%$. The Arizona Department of Health Services has developed a health-based guidance level of $14 \mu \mathrm{g} / \mathrm{L}$ based on a provisional oral reference dose of $0.9 \mu \mathrm{g} / \mathrm{kg}$ day (41) but with adjustments in intake rates and body weights aimed to be specifically protective of childhood exposure (42). The NAS report supported a reference dosage of $0.7 \mu \mathrm{g} / \mathrm{kg}$ based on a NOAEL of $7 \mu \mathrm{g} / \mathrm{kg}$ from human iodide uptake studies (40) to which a 10-fold uncertainty factor was applied to address acute and chronic exposures of all potentially sensitive populations (43). After the NAS report, EPA modified their DWEL to $0.7 \mu \mathrm{g} / \mathrm{kg}$ but OHHEA retained their public health goal of $6 \mu \mathrm{g} / \mathrm{L}$. A comparison of exposure and dosage estimates from a daily serving of lettuce show the potential contribution from lettuce is below all of the proposed standards. For all lettuce types and trims, potential exposure to 
Table 4. Hypothetical Perchlorate Exposures Derived from Lettuce Irrigated with Colorado River Water

\begin{tabular}{|c|c|c|c|c|}
\hline lettuce type & $\begin{array}{c}\text { perchlorate } \\
\text { concentration range }\end{array}$ & $\begin{array}{c}\text { mean }^{a} \\
(\mu \mathrm{g} \text { of perchlorate } / \mathrm{kg} \text { of lettuce) }\end{array}$ & $\begin{array}{c}\text { exposure }^{b} \\
\text { ( } \mu \mathrm{g} \text { of perchlorate/day) }\end{array}$ & $\begin{array}{c}\text { adult male dosage } \\
\text { ( } \mu \mathrm{g} \text { of perchlorate } / \mathrm{kg} \text { of } \mathrm{bw} \text { ) }\end{array}$ \\
\hline \multicolumn{5}{|l|}{ iceberg } \\
\hline naked & ND to $33 \mu \mathrm{g} / \mathrm{kg}$ & 14 & 0.75 & 0.011 \\
\hline wrapped & ND to $24 \mu \mathrm{g} / \mathrm{kg}$ & 10 & 0.52 & 0.007 \\
\hline bulk & $\mathrm{ND}$ to $<\mathrm{MRL}$ & 8 & 0.45 & 0.006 \\
\hline \multicolumn{5}{|l|}{ romaine } \\
\hline naked & ND to $47 \mu \mathrm{g} / \mathrm{kg}$ & 23 & 1.3 & 0.018 \\
\hline bulk & ND to $20 \mu \mathrm{g} / \mathrm{kg}$ & 13 & 0.70 & 0.010 \\
\hline hearts & $N D$ to $<M R L$ & 12 & 0.64 & 0.009 \\
\hline green leaf & ND to $102 \mu \mathrm{g} / \mathrm{kg}$ & 33 & 1.8 & 0.026 \\
\hline red leaf & ND to $81 \mu \mathrm{g} / \mathrm{kg}$ & 27 & 1.5 & 0.021 \\
\hline butterhead & $\mathrm{ND}$ to $104 \mu \mathrm{g} / \mathrm{kg}$ & 29 & 1.6 & 0.023 \\
\hline
\end{tabular}

\footnotetext{
${ }^{a}$ Each mean is the average of 24 values and includes ND $=5 \mu \mathrm{g} / \mathrm{kg}$ of fw and $<\mathrm{MRL}=10 \mu \mathrm{g} / \mathrm{kg}$ of fw for iceberg lettuce and $15 \mu \mathrm{g} / \mathrm{kg}$ of fw for all other lettuce types and quantifiable values. ${ }^{b}[\mu \mathrm{g}$ of perchlorate $/ \mathrm{kg}$ of lettuce $\times 0.055 \mathrm{~kg}] / 70 \mathrm{~kg}$ of bw $=\mu \mathrm{g}$ of perchlorate $/ \mathrm{kg}$ of bw. MRL $=$ minimum reporting levels assigned in tables. ND $=$ none detected at 5 ppb. Lettuce consumption, 55 g/day (Smiciklas-Wright et al., 2002). Adult male body weight (bw), $70 \mathrm{~kg}$ (USEPA, 1997).
}

Table 5. Hypothetical Perchlorate Exposures and Dosages Equivalent to Drinking Water Advisory Levels

\begin{tabular}{lccccc}
\hline source & $\begin{array}{c}\text { "advisory" } \\
\text { water perchlorate } \\
\text { level }(\mu \mathrm{g} / \mathrm{L})\end{array}$ & $\begin{array}{c}\text { daily exposure } \\
\text { from water } \\
(\mu \mathrm{g})^{a}\end{array}$ & $\begin{array}{c}\text { total daily } \\
\text { exposure } \\
(\mu \mathrm{g})\end{array}$ & $\begin{array}{c}\text { equivalent perchlorate } \\
\text { dosage from water } \\
(\mu \mathrm{g} / \mathrm{kg} \mathrm{of} \mathrm{bw})^{b}\end{array}$ & $\begin{array}{c}\text { equivalent perchlorate } \\
\text { dosage from all sources } \\
(\mu \mathrm{g} / \mathrm{kg} \text { of bw })\end{array}$ \\
\hline USEPA & & & & & 0.17 \\
California & 6 & 12 & 20 & 0.40 & 0.70 \\
Arizona & 14 & 28 & 28 & & 0.70 \\
NAS & & & & & \\
\end{tabular}

${ }^{a}$ Assumes adult intake of $2 \mathrm{~L}$ of water. ${ }^{b}$ Assumes average adult male body weight of $70 \mathrm{~kg}$.

Table 6. Total Nitrate Concentrations, Perchlorate Equivalent Nitrate Concentrations (PEC), and Estimated Potential lodide Uptake Inhibition Potential of the NIS by Nitrate Relative to Perchlorate for Lettuce Irrigated with Colorado River Water

\begin{tabular}{cccc}
\hline $\begin{array}{c}\text { lettuce type } \\
\text { and trim }\end{array}$ & $\begin{array}{c}\text { nitrate } \\
(\mu \mathrm{g} / \mathrm{kg} \text { of fw })\end{array}$ & $\begin{array}{c}\text { PECa of nitrate } \\
(\mu \mathrm{g} / \mathrm{kg} \text { of fw })\end{array}$ & $\begin{array}{c}\text { potential iodide uptake inhibition potential } \\
\text { of nitrate relative to perchlorate }{ }^{b}\end{array}$ \\
\hline $\begin{array}{c}\text { iceberg } \\
\text { naked }\end{array}$ & $1.4 \times 10^{6}\left(4.8 \times 10^{5}\right)^{\mathrm{c}}$ & 5656 & 400 \\
wrapped & $1.5 \times 10^{6}\left(6.5 \times 10^{5}\right)$ & 5906 & 600 \\
bulk & $1.4 \times 10^{6}\left(3.7 \times 10^{5}\right)$ & 5578 & 700 \\
romaine & $1.8 \times 10^{6}\left(6.0 \times 10^{5}\right)$ & 7163 & 300 \\
naked & $1.7 \times 10^{6}\left(7.2 \times 10^{5}\right)$ & 6697 & 500 \\
bulk & $1.6 \times 10^{6}\left(5.2 \times 10^{5}\right)$ & 6374 & 500 \\
hearts & $1.8 \times 10^{6}\left(6.4 \times 10^{5}\right)$ & 7145 & 200 \\
green leaf & $1.8 \times 10^{6}\left(5.8 \times 10^{5}\right)$ & 7129 & 250 \\
red leaf & $1.9 \times 10^{6}\left(5.6 \times 10^{5}\right)$ & 7548 & 250 \\
butter & & &
\end{tabular}

\footnotetext{
a Perchlorate equivalent concentration (PEC) of nitrate, where $\mathrm{PEC}=\left[\mathrm{NO}_{3}\right] / 250$ on a concentration basis $\left(\mu \mathrm{g} / \mathrm{kg}\right.$ of fresh weight). ${ }^{b} \mathrm{Calculated}$ by $\left(\mathrm{PEC}\right.$ for $\left.\left.\mathrm{NO}_{3}\right) /(\mathrm{ClO})_{4}\right)$. Values are rounded to the nearest 50 because estimates are approximate. ${ }^{c}$ Values in parentheses show standard deviation.
}

perchlorate (Table 4) was less than $4 \%$ of the reference dosage of $0.7 \mu \mathrm{g} / \mathrm{kg}$ proposed by the NAS.

Another consideration in the biological significance of trace levels of perchlorate is its presence and potency relative to natural goitrogens in food. One of these, nitrate, occurs in lettuce naturally (5). A number of studies have determined the relative potency of perchlorate and nitrate as iodide uptake inhibitors of the NIS in laboratory rats $(2,44,45)$. These studies report relative molar potency estimates of perchlorate to nitrate ranging from 240 to 400. More recently, Toncchrahera et al. (3) evaluated the relative potency of perchlorate, thiocyanate, and nitrate in vitro using Chinese hamster ovary cells expressing human NIS and reported a relative molar potency of perchlorate to nitrate of 240 and of perchlorate to thiocyanate of 15. Overall, a conservative estimate of perchlorate equivalent concentration (PEC) of nitrate is (nitrate/250) on an ingested weight basis.

Nitrate concentrations in lettuce collected in these studies ranged from $1.4 \times 10^{6}$ to $1.9 \times 10^{6} \mu \mathrm{g} / \mathrm{kg}$ of fw (Table 6) and are in range of lettuce nitrate contents reported in other studies $(4,5)$. The PEC of nitrate ranged from $2 \times 10^{3}$ to $7 \times 10^{3}$ $\mu \mathrm{g} / \mathrm{kg}$ of fw. Using these calculated mean PEC values in Table $\mathbf{6}$ and mean perchlorate values in Table 5, we estimate that the relative iodide uptake inhibition to nitrate is 2 orders of magnitude higher than that associated with the trace levels of perchlorate found in lettuce produced in the Lower Colorado River region. This observation is consistent with conclusions made concerning natural goitrogens in a wide variety of food products (46) and illustrates the paradox of assigning risk to trace levels of perchlorate in food. It has been suggested that changes in thyroid hormone synthesis rather than transitory reduction in iodide uptake be utilized as the end point of concern, but this debate is beyond the scope of this paper.

The presence of natural goitrogens in food is widely recognized (47-49) and is a significant reason that iodized salt is utilized in the United States and other nations. Iodine status may be more important than perchlorate exposure in human 
health (50), and this lettuce study reported here was not designed to address the iodine status of the population. However, if iodide intake is sufficient to counter any potential adverse affects of natural giotrogens, there is very little or no risk associated with the trace levels of perchlorate that we have found in lettuce.

In conclusion, the Colorado River is contaminated with low levels of perchlorate and lettuce irrigated with this water accumulates trace levels of perchlorate. However, on the basis of this extensive produce study, other available data, and consistent with recent recommendations of the NAS, we conclude that these trace levels of perchlorate found in lettuce pose a negligible health risk.

\section{LITERATURE CITED}

(1) Clark, J. J. Perchlorate toxicology. In Perchlorate in the Environment; Urbansky, E. T., Ed.; Kluwer/Plenum: New York, 2000; chapter 1.

(2) Wyngaarden, J. B.; Stanbury, J. B.; Rapp, B. The effects of iodide, perchlorate, thiocyanate, and nitrate administration upon the iodide concentrating mechanism of the rat thyroid. Endocrinology 1953, 52, 568-574.

(3) Tonacchera, M.; Pinchera, A.; Dimida, A.; Ferrarini, E.; Agretti, P.; Vitti, P.; Santini, F.; Crump, K.; Gibbs, J. Relative potencies and additivity of perchlorate, thiocynanate, nitrate, and iodide on the inhibition of radioactive iodide uptake at the sodium iodide symporter. Thyroid 2005, 14, 1012-1019.

(4) Petersen, A.; Stoltze. S. Nitrate and nitrite in vegetables on the Danish market: Content and intake. Food Addit. Comtam. 1999, 16, 291-299.

(5) Ysart, G.; Clifford, R.; Harrison, N. Monitoring for nitrate in UK-grown lettuce and spinach. Food Addit. Contam. 1999, 16, 301-306.

(6) DHS. Standards for perchlorate in drinking water. Department of Health Services, Sacramento, CA. 2000, www.dhs.cahwnet.gov/org/ps/.

(7) Urbansky, E. T.; Magnuson, M. L.; Kelty, C. A.; Brown, S. K. Perchlorate uptake by salt cedar (Tamarix ramosissima) in the Las Vegas Wash riparian ecosystem. Sci. Total Environ. 2000, 256, 227-232.

(8) Smith, P. N.; Yu, L.; McMurry, T.; Anderson, T. A. Perchlorate in water, soil, vegetation, and rodents collected from the Las Vegas Wash Nevada, U.S.A. Environ. Pollut. 2004, 132, 121127.

(9) Ellington, J. J.; Wolfe N. L.; Garrison, A. W.; Evans, J. J., Avants, J. K.; Teng, Q. Analysis of perchlorate in tobacco plants and tobacco products. Environ. Sci. Technol. 2001, 35, 32133218.

(10) Nzengung, V. A.; Wang, C.; Harvey, G. Plant-mediated transformation of perchlorate into chloride. Environ. Sci. Technol. 1999, 33, 1470-1478.

(11) Susarla, S. S.; Baccus, T.; N.; Wolfe, N. L.; McCutcheon, S. C. Phytotransformation of perchlorate and identification of metabolic products in Myriophyllum aquaticum. Int J. Phytorem. 1999, 1, 97-107.

(12) Moyer, B. A.; Bonnesen, P. V. Physical factors in anion separations. In Supramolecular Chemistry of Anions; Bianchi, A., Bowman-James, K., Espana, G., Eds.; Wiley-VCH: New York, 1997; chapter 1.

(13) Cataldo, D. A.; Garland, T. A.; Wildung, R. E. Plant root absorption and metabolic fate of technetium in plants. In Technetium in the Environment; Desmet, G., Myttenaere, C., Eds.; Elsevier London: U.K., 1986; chapter 22.

(14) Echevarria, G.; Vong, P. C.; Leclerc-Cessac, E. Bioavailability of technetium 99 as affected by plant species and growth, application form, and soil incubation. J. Environ. Qual. 1997, 26, 947-956.

(15) Yu, Lu; Canas, J. E.; Cobb, G. P.; Jackson, W. A.; Anderson, T. A. Uptake of perchlorate in terrestrial plants. Ecotoxicol. Environ. Saf. 2004, 58, 44-49.
(16) Jackson, W. A.; Joseph, P.; Laxman, P.; Tan, K.; Smith, P. N.; $\mathrm{Yu}, \mathrm{L}$.; Anderson, T. A. Perchlorate accumulation in forage and edible vegetation. J. Agric. Food Chem. 2005, 53, 369-373.

(17) Hutchinson, S. T. A study on the accumulation of perchlorate in young head lettuce. www.epa.gov/athens/publications/ Pub2004.html and EPA report EPA/600/R-03/003. 2004.

(18) EWG. 2003. http/www.efg.og/reports/rocketlettuce/.

(19) FDA. Exploratory data on perchlorate in food. 2004. http:// www.cfsan.fda.gov/ dms/clo4data.

(20) Ericksen, G. E. The Chilean nitrate deposits. Am. Sci. 1983, 71, 366-374.

(21) Urbansky, E. T., Collette, T. W.; Robarge, W. P.; Hall, W. L., Skillen, J. M.; Kane. P. F. Survey of fertilizers and related materials for perchlorate $\left(\mathrm{ClO}_{4}^{-}\right)$. Final Report. EPA/600/R-01/ 047. 2001.

(22) Orris, G. J.; Harvey, G. J.; Tsui, D. T.; Eldrige, J. E. Preliminary analyses for perchlorate in selected materials and their derivative products. USGS Report 03-314. 2003.

(23) Dagupta, P. K.; Martinelango, P. K.; Jackson, W. A.; Anderson, T. A.; Tian, K.; Tock, R. W.; Rajagopalan, S. The origin of naturally occurring perchlorate: The role of atmospheric proceses. Environ. Sci. Technol. 2005, in press.

(24) Ellington, J. J.; Evans, J. J. Determination of perchlorate at partsper-billion levels in plants by ion chromatography. J. Chromatogr. 2000, 898, 193-199.

(25) U.S. EPA. U.S. EPA Method 314.0. Determination of perchlorate in drinking water using ion chromatography. U.S. Environmental Protection Agency. National Exposure Research Laboratory and Office of Research and Development, Cincinnati, OH 45268. 1999.

(26) Baker, A. S.; Smith, R. Extracting solution for potentiometric determination of nitrate in plant tissue. J. Agric. Food Chem. 1969, 17, 1284-1287.

(27) Smiciklas-Wright, H.; Mitchell, D. C.; Mickle S. J.; Cook, A. J.; Goldman J. D.;. Foods Commonly Eaten in the United States. Quantities Consumed Per Eating Occasion and in a Day, 19941996. USDA NFS report number 96-5. 2002.

(28) Arizona Department of Environmental Quality. Perchlorate in Arizona: Occurrence study of 2004.

(29) Urbansky, E. T.; Brown, S. K. Perchlorate retention and mobility in soils. J. Environ. Monit. 2003, 5, 1-9.

(30) Tipton, D. K.; Rolston, D. E.; Snow, K. M. Transport and biodegradation of perchlorate in soils. J. Environ. Qual. 2003, $32,40-46$.

(31) Erie, L. J.; French, O. F.; Bucks, D. A.; Harris, K. Consumptive use of water by major crops in the Southwestern United States. USDA-ARS. Conservation Research Report Number 29, 1982.

(32) Martin, E. C.; Pegelow, E. J.; Slack, D. C. Vegetable Water UseWestern Head Lettuce. Cooperative Extension Publication, AZ1132, College of Agriculture, University of Arizona. 1999; 2 pages.

(33) Sundberg, S. E.; Ellinghton, J. J.; Evans, J. J.; Keys, D. A.; Fisher, J. W. Accumulation of perchlorate in tobacco plants: Development of a plant kinetic model. J. Environ. Monit. 2003, 5, $1-9$.

(34) Coates, J. D.; Michaelidou, U.; O’Connor, S. M.; Bruce, R. A.; Achenbach, L. A. The diverse microbiology of perchlorate reduction. In Perchlorate in the Environment; Urbansky, E. T., Ed.; Kluwer/Plenum: New York, 2000; chapter 24.

(35) Nzengung, V. A.; Penning, H.; O'Niell, W. Mechanistic changes during phytoremediation of perchlorate under different root zone conditions. Int. J. Phytorem. 2004, 6, 63-83.

(36) van Aken, B.; Schnoor, J. L. Evidence of perchlorate $\left(\mathrm{ClO}_{4}^{-}\right)$ reduction in plant tissue using radio-labeled ${ }^{36} \mathrm{ClO}_{4}^{-}$. Environ Sci. Technol. 2002, 36, 2783-2788.

(37) Krynitsky, A. J.; Niemann, R. A.; Nortrup, D. Determination of perchlorate anion in foods by ion chromatography-tandem mass spectroscopy. Anal. Chem. 2004, 76, 5528-5522.

(38) USEPA. Perchlorate Environmental Contamination: Toxicological review and risk characterization (External Review Draft) 
U.S. Environmental Protection Agency, Office of Research and Development, Washington, DC. NCEA-1-0503. 2002.

(39) OEHHA. Public health goal for perchlorate in drinking water. Office of Environmental Health Hazard Assessment of the California Environmental Protection Agency. March 2004.

(40) Greer, M. A.; Goodman, G.; Pleus, R. C.; Greer, S. E. Health effects assessments for environmental perchlorate: The dose response for inhibition of radioiodide uptake in humans. Environ. Health Perspect. 2002, 110, 927-937.

(41) USEPA. Perchlorate Environmental Contamination: Toxicological review and risk characterization based on emerging information (External Review Draft). U.S. Environmental Protection Agency, Office of Research and Development, Washington, DC. NCEA-1-0503. 1998.

(42) Arizona Department of Health Services. Health based guidance level for perchlorate $\left(\mathrm{ClO}_{4}\right)$. Office of Environmental Health. 2000.

(43) National Academy of Science. Health implications of perchlorate ingestion. National Research Council. Prepublication Copy, January 2005.

(44) Alexander, W. D.; Wolff, J. Thyroidal iodide transport VIII, Relation between transport, goitrogenic, and antigoitrogenic properties of certain anions. Endocrinology 1966, 78, 581590 .
(45) Greer, M. A.; Stout, A. K.; Miline, K. A. Effects of thiocyanate, perchlorate, and other anions on thyroidal iodide metabolism. Endocrinology 1966, 79, 237-247.

(46) Belzer, R. B.; Bruce, G. M.; Peterson, M. K.; Pleus, R. C. Using comparative exposure analaysis to validate low-dose human health risk assessment: The case for perchlorate. In Comparative Risk Assessment and Environmental Decision Making; Linkov, I., Ramadan A., Ed.; Kluwer: New York, 2004.

(47) Clemments, F. W. Naturally occurring goitrogens. Brit. Med. Bull. 1960, 16, 133-137.

(48) Greer, M. A. The natural occurrence of goitrogenic agents. Recent Prog. Horm. Res. 1962, 18, 187-219.

(49) VanEtten, C. H. Goitrogens. In Toxic Constituents of Plant Foodstuffs; Lenier, I. E., Ed.; 1969; chapter 4, pp 103-134.

(50) National Academy of Science. Recommended Dietary Allowances (10th), National Research Council, National Academy Press: Washington, DC, 1989.

Received for review February 17, 2005. Revised manuscript received April 22, 2005. Accepted April 30, 2005. We gratefully acknowledge the support of the Arizona Iceberg Lettuce Research Council, the California Lettuce Research Board, and the USDA-ARS.

JF050380D 